\title{
Seismic Risk Assessment of Historical Eastern Turkish Buildings by Finite Element Analysis
}

\author{
A.I. ÇARHOGLU ${ }^{a}$, P. Usta ${ }^{a, *}$, K.A. KORKMAZ ${ }^{b}$ \\ ${ }^{a}$ Suleyman Demirel University, Department of Civil Engineering, Isparta, Turkey \\ ${ }^{b}$ Istanbul Technical University, Department of Civil Engineering, Istanbul, Turkey
}

\begin{abstract}
Traditional masonry buildings, commonly built in Turkey, are one of the important items of cultural heritage. There are many important historical buildings in the east part of Turkey. One of the important locations in east of Turkey is Kilis. In this study, Kilis houses of original types in terms of architectural and functionality, were examined regarding the effects of an earthquake. Therefore, five traditional Kilis houses were examined and the buildings were modeled using SAP2000 finite element software. The models were investigated with different materials such as stone, brick, pumice and cellular concrete material. Time history analyses were performed for the modeled buildings, with three different ground motion records. Displacement values, compressive stresses, tensile stresses, shear stresses and base shear values, obtained from the analysis results were examined in detail. When the results of the study were evaluated, earthquake resistance of buildings was was found to be high and the displacements values were not at a significant level.
\end{abstract}

DOI: $10.12693 /$ APhysPolA.127.1083

PACS: 47.11.Fg, 81.90.+c, 82.20.Wt

\section{Introduction}

Eastern part of Turkey is full of history. One of the important locations in East of Turkey is Kilis. Throughout the history, due to its nature and geography, Kilis has hosted many civilizations such as the Babylonian, Hittite, Persian, Roman, Byzantine, Seljuk and Ottoman. Moreover, it has played a role of center of many civilizations such as Mesopotamia, Syria and Egypt. These civilizations have brought many monuments and signature buildings as well as a profound culture [1]. Traditional Turkish houses are the kind of buildings which were formed within the borders of the Ottoman Empire and became identified with its own characteristics at a certain time. Generally, the number of the stories of buildings, which used to be a single store, had increased with time. The construction materials used in these buildings are wood, stone and mud-brick and stone material [2-3]. The wall thickness of the houses constructed as masonry, has ranged from 70 to $100 \mathrm{~cm}$. Historical houses reflect the history of society, culture and living style of the period in which they were built. In Kilis architecture, big open areas such as courtyards are seen. The big openings and the places, where every kind of need can be met, are noticeable in the architecture of traditional Kilis houses. The large courtyards in Kilis houses led the way for the cities spread on a wide area. The rectangular or square shaped courtyards, with a pool from stone in the middle of Kilis houses, are the meeting points of the plan as well functionally and formally [4].

\footnotetext{
* corresponding author; e-mail: pinarusta@sdu.edu.tr
}

\section{Seismicity of Kilis}

Kilis is located in the southwestern part of Gaziantep Plateau, extending between Firat River and Hatay-Maras Groove in Southeastern Anatolia Region, and it is in the transition zone between the Mediterranean and Southeast regions $[5,6]$. Kilis is in the third degree seismic zone. In the past, three devastating earthquakes in 1738 , 1807 and 1820 have occurred. The most devastating one of these earthquakes, is the one occurred in 1820. In this earthquake, many buildings were destroyed. Moreover, one of the most famous mosques, Kadı Mosque was demolished during the earthquake and then it was repaired. Ulu Mosque minaret was damaged in earthquake of 1807 and was repaired in subsequent years [7].

\section{The finite elements modeling of Kilis houses and determination of earthquake behavior}

In this study, five different buildings from the traditional historical Kilis houses were considered. These buildings were modeled with Sap 2000 program [8] assuming the floors are rigid. When modeling the structures, solid element was used in the walls and shell element was used in the part of the roof. Each building was formed from the solid and shell elements, which have different number node, according to their dimensions and mechanical properties. Modeled Kilis houses are seen in Fig. 1. Kilis houses ( Barışkan, Neci, Salihoğlu, Tümay, Üzümbalı) were modeled by finite elements method, and with different materials such as stone, brick, pumice and cellular concrete material.

The earthquake behavior of the traditional Kilis houses was examined by addressing the stone, brick, pumice and cellular concrete cases. Material properties for these cases are shown in Table. 

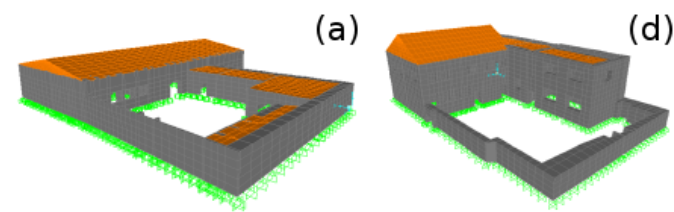

(b)

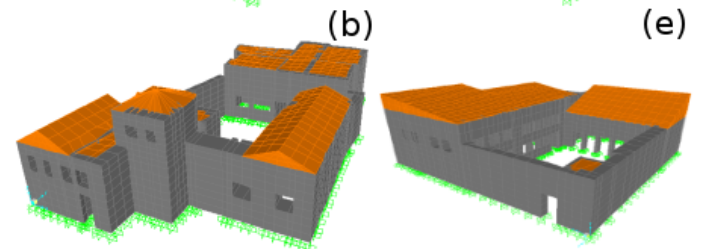

(c)

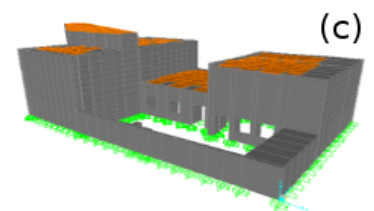

Fig. 1. Kilis houses modeled by finite element method, (a) Barışkan, (b) Neci, (c) Salihoğlu, (d) Tümay, (e) Üzümbalı.

Material properties.

TABLE

\begin{tabular}{c|c|c|c}
\hline \hline Material & $\begin{array}{c}\text { Modulus of } \\
\text { elasticity } \\
{[\mathrm{MPa}]}\end{array}$ & $\begin{array}{c}\text { Poisson } \\
\text { ratio }\end{array}$ & $\begin{array}{c}\text { Unit volume } \\
\text { weight } \\
{\left[\mathrm{kN} / \mathrm{m}^{3}\right]}\end{array}$ \\
\hline Stone walls & 20000 & 0.2 & 25 \\
Brick & 3000 & 0.2 & 20 \\
Pumice & 22000 & 0.2 & 16 \\
Cellular concrete & 25000 & 0.2 & 6
\end{tabular}

\section{The analysis of results for Kilis houses}

In this study, the behavior of the models under the effect of earthquake was investigated by using three different ground motion records of Cape Mendocino, Kobe, and Anza earthquakes. In the analysis, the values of the displacement in $X$ and $Y$ directions for each ground motion record, applied to the buildings, were obtained and the results are demonstrated graphically. The maximum values of displacement in $X$ and $Y$ directions, obtained from the analysis results, are shown in Fig, 2-6. As shown in Fig. 2-6, the maximum values of displacement were obtained for combination of Kobe earthquake and brick material. The lowest values were obtained for Anza earthquake and cellular concrete.

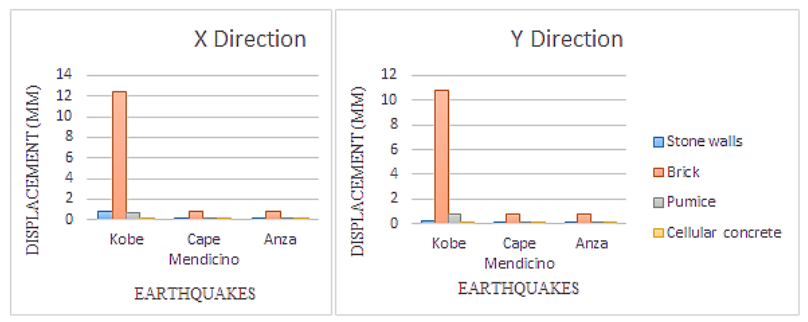

Fig. 2. $X$ and $Y$ displacement values for Neci houses.

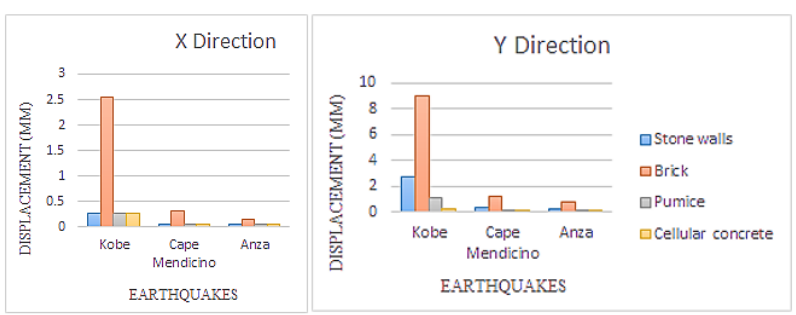

Fig. 3. $X$ and $Y$ displacement values for Barışkan houses.

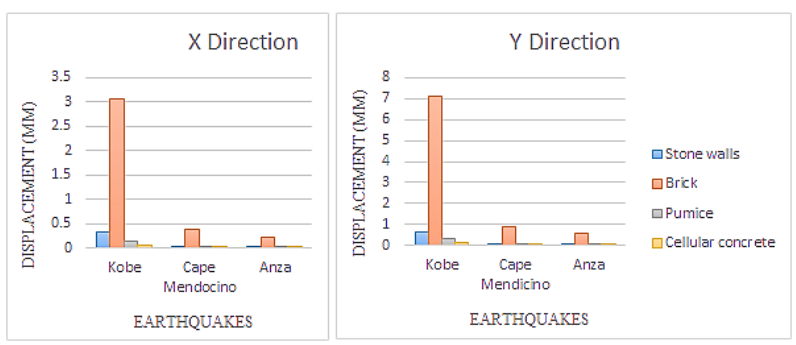

Fig. 4. $X$ and $Y$ displacement values for Salihoğlu houses.

\section{Conclusions}

In this study, five historical, traditional Kilis houses were modeled with brick, pumice, stone and cellular concrete materials. Three different ground motion records were applied to the buildings by using time history analysis method for four different material cases. The reliability of the models under the effect of earthquake were determined by comparing results for different materials. The natural vibration periods obtained for each structure, are on the acceptable level for the masonry buildings. When the values of displacement, tension, shear stress were examined, it was seen that the maximum values were obtained for Kobe earthquake. When the displacement values were compared, it was seen that the values have varied according to the dimensions, height and material properties of the structures. The maximum displacement values have occurred in the structures composed from brick, stone, pumice and cellular concrete materials, respectively.

Considering all these features, the small height and number of the stories of these buildings and the large thickness of the walls, the displacement values for these

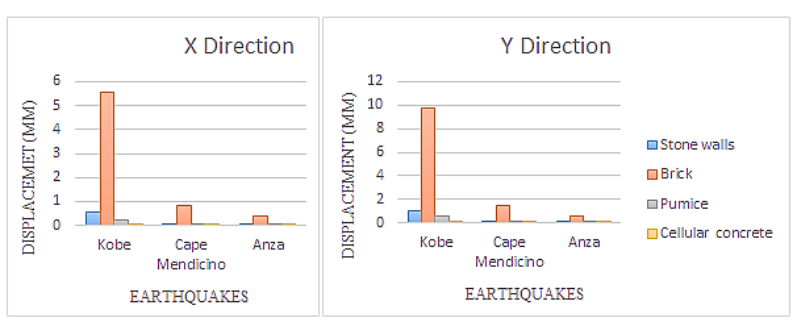

Fig. 5. $X$ and $Y$ displacement values for Tümay houses. 


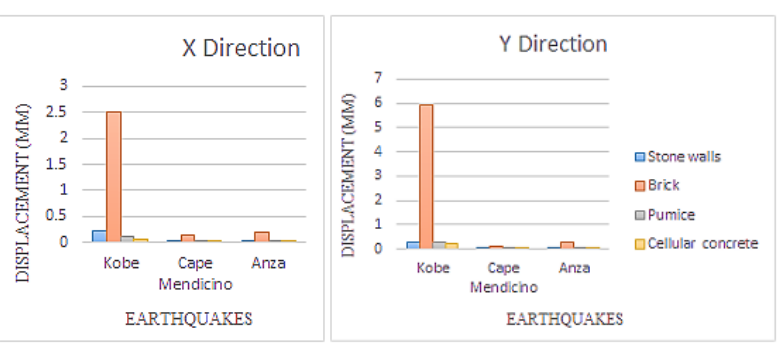

Fig. 6. $X$ and $Y$ displacement values for Üzümbalı houses.

buildings can be based on the differences in the properties of the applied material. As a result of the analysis, the maximum displacement values have occurred in the building modeled with brick material, which has the smallest elasticity modulus. These are followed by displacement values for buildings modeled with cellular concrete, stone and pumice materials, respectively. While the maximum displacement value (of $12.47 \mathrm{~mm}$ ) has occurred in the structure made from brick material at Kobe earthquake, the minimum displacement value (of $0.78 \mathrm{~mm}$ ) was obtained at Anza earthquake. The maximum displacement values in all models have occurred in Kobe earthquake, which was followed by Cape and Anza earthquakes. It was seen that the displacements in the structures, ordered from large to small, are distributed as follows: Neci, Tümay, Salihoğlu, Barışkan and Üzümbalıhouses.

\section{References}

[1] http://www.kilis.bel.tr.

[2] S.E. Atacan, Traditional Gaziantep houses plan and the form properties, Ankara, 1996.

[3] N. Bayülke, Depreme Dayanıklı Betonarme ve Yığma Yapı Tasarımı, İnşaat Mühendisleri Odası İzmir Şubesi Yayın, No 27, 245s., İzmir (1998).

[4] R. Savaşçığlu, Historical Kilis Houses, Selçuk Üniversitesi Graduate School Architecture, MSc Thesis, 2008.

[5] http://www.tr.wikipedia.org/wiki/Kilis.

[6] Çevre ve Shehircilik Bakanlığ iği Çevre ve Şehircilik il Müdürlüğ̈̈, http: //www.csb.gov.tr/iller/kilis/index.php?Sayfa= say fa\&Tur=webmenu\& $I d=2564$.

[7] A. Dündar, Architecture of the Ottoman Period in Kilis, Ankara, 1999.

[8] SAP2000, Three Dimensional Static and Dynamic Finite Element Analysis and Design of Structures, Computer and Structures Inc., Berkeley, California, USA, 1998. 